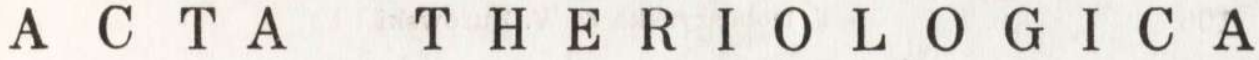

VOL. 20, 8: 105-112.

April, 1975

Teresa DOBOSZYNSKA \& Wirgiliusz ŻUROWSKI

\section{Changes Observed in the Reproductive Tract of a Beaver Female After High Dosages of Gonadotropic Hormones}

[With 3 Tables \& Plates III-IV]

\begin{abstract}
In an experiment on hormonal directing of the reproduction of European beavers (Castor fiber L in na e u s, 1758), female no. 35 received for 13 days in the autumn $5 \mathrm{mg}$ of oestrogen and $70 \mathrm{mg}$ of progesteron, followed by $1000 \mathrm{IU}$ of PMSG and a $1000 \mathrm{IU}$ of HCG. On the 14th day after the last injection of gonadotropine, the female was killed. The reproductive tract was subjected to histological investigations. It was ascertained that the hormones administered caused a protracted superovulation, lasting more than ten days. This was accompanied by changes characteristic for the luteal phase of the reproductive tract. Thus two phases of the oestrus cycle overlapped. It was also observed an excessive growth of the reproductive organs, caused probably by a surplus of gonadotropic hormones.
\end{abstract}

\section{INTRODUCTION}

Beavers fall within the group of animals with a seasonal breeding period. The mating season is in January and February. In this period the females not fertilised repeat the oestrus from two to four times. In the case of fertilisation, after about 107 days, the kits are born. The lactation lasts, in farm conditions, up to 3 months, but the kits consume the fodder prepared for adult beavers after the first month of lactation. Thus beavers have a very long period of breeding inactivity. Investigations carried out by Doboszyńska (1974) on dead females demonstrated, that this period is not tantamount to a complete inhibition of oogenesis. Ovaries are active throughout the year and produce gametes of various intensity. I va n o va (1961) ascertained a seasonal spermatogenesis in the males of the European beaver. She maintained that the intensification of spermatogenesis falls in January and February, following which, until the end of May there occurs a decrease in gametogenesis, and from June to October a complete inhibition of spermatogenesis. However, in 
farm animals there occurs considerable deviations from the pattern presented. Lavrov (1960) records that on a farm near Voronezh kits from Canadian beavers were obtained in August. On the farm in Popielno, parturitions of European beavers occurred on July 9th, and August 12 th and 16 th - i.e., in the later case a successful fertilisation took place on May 2nd.

It seems that the existing deviations in the breeding seasonality of beavers offer opportunities for human intervention in the reproductive processes, at least for scientific purposes. With a view to a better apprehension of the reproductive processes of European beavers (Castor fiber $\mathrm{L}$ in $\mathrm{n}$ a e us, 1758), experiments were undertaken at the experimental farm in Popielno concerned with provoking oestrus and ovulation. These experiments were based on the results of works on the stimulation of oestrus and ovulation in domestic animals, principally sheep, during anoestrus (Donovan, 1967; Gemzell, 1967; Robinson, 1967, 1970; D o mánski, 1970; Jöhle, 1970; K a r g, 1970; K a r d y mowicz, 1970; Kremer, 1970; Gordon, 1971). Among the experimental females in Popielno subjected to the acttivity of gonadotropin hormones, one died accidentally from a mechanical injury 14 days after the hormone injection. This paper is concerned with an examination of the condition of the reproductive system of this female.

\section{MATERIAL AND METHODS}

Female no. 35, born in 1964, produced on the farm 8 young in 3 litters. In October 1971, in the period proceding the natural mating season, the female received a subcutaneous injection of $5 \mathrm{mg}$ of stilbestrol and $10 \mathrm{mg}$ of syntolutane (progesterone). Then, every second day during a period of 12 days it received $10 \mathrm{mg}$ of syntolutane, $70 \mathrm{mg}$ in all. After this preparatory period it received on November ist 1000 IU PMSG and on November 4th 1000 IU of HCG, both intramuscularly. It died as a result of mechanical injury on November 18th. Immediately following its death an autopsy was performed and the generative organs measured. Material was taken for histological examination. The ovaries were taken whole, while from the oviducts, uterus and vagina segments were taken from various parts. For fixation, $A F A$ and Bouin fluid was used. From both the ovaries serial specimens were prepared, stained by the method devised by Mallory. Paraffin cuttings from the remaining organs were stained by hematoksylin-eozyn and Mallory's method.

On the basis of serial specimens of the ovaries calculations were made of the absolute number of primary and growing follicles, mature and atretic Graafian follicles and of corpora lutea. Additionally, using the drum micrometer, measurements were taken of the diametres of the elements referred to of the ovary. On micrographs of transverse specimens, using the polar planimeter, the area was measured of the vascular and follicular layers. Their arithmetical means were calculated. 
Analogous data were gathered from 2 control females, not subjected to hormonal treatment, which died during the mating season. These were: female no. 69, born 1967 , died January 23rd 1970, and female no. 106, born 1969, died January 18th 1970,

\section{RESULTS}

In female no. 35 , after the administration of hormones only a slight agitation was observed, demonstrated by increased mobility. No typical external symptoms of oestrus, such as characteristic noises, and excretions from the reproductive tract, were observed. Also, the male was not interested.

Table 1

Measurements of reproductive organs of females investigated (linear measurements in $\mathrm{mm}$, ovary weight in $\mathrm{mg}$ ).

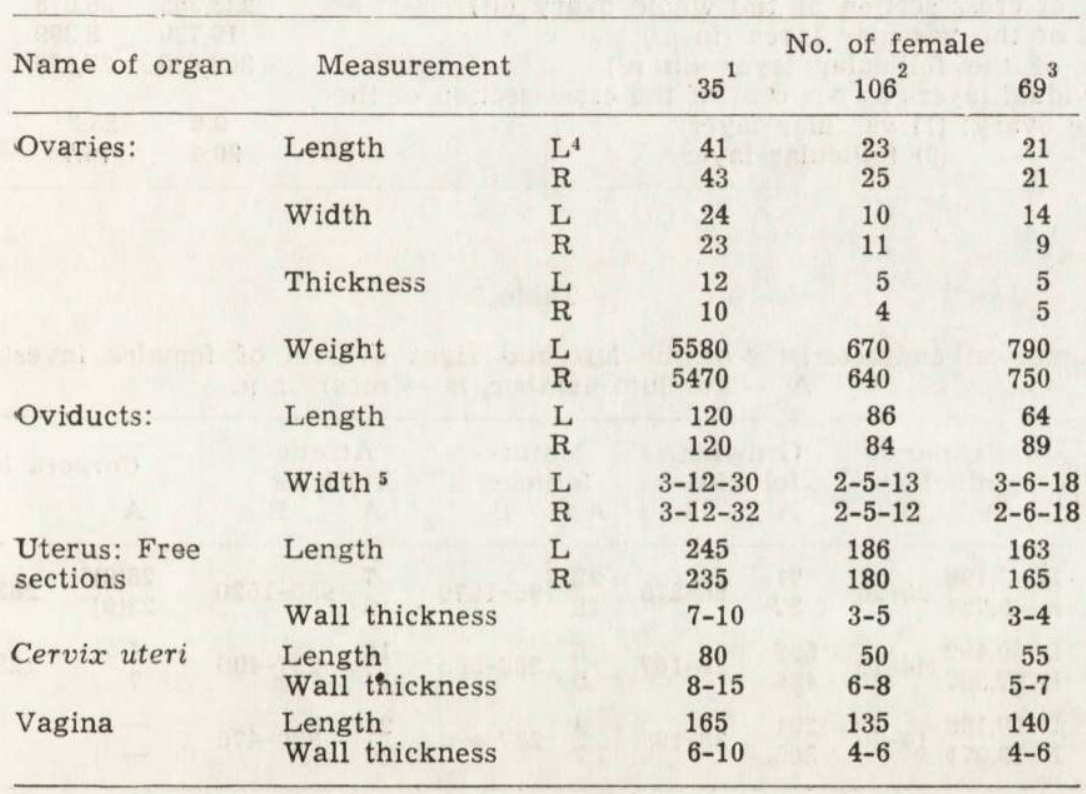

1 Experimental; ${ }^{2}$ Control in the follicular phase; ${ }^{3}$ Control in the phase of corpora lutea; ${ }^{4} \mathrm{~L}-$ left, $\mathrm{R}-$ right; 5 Isthmus-follicle-infundible of uterine.

During the autopsy, a general enlargement and softening of the reproductive tract was observed, and an enlargement of the ovaries. The measurements made indicated an abnormal enlargement of those organs by comparison with control animals (Table 1). Protruding Graafian follicles and follicles freshly disrupted were observed on the ovaries. The weight of ovaries from the female investigated was 8 times that of the control animals (Table 1). 
The area of the cross-sections of ovaries was found to be 5 times that of the ovaries of control females. A particularly unusual growth of ovaries occurred in the follicular layer, the area of which constituted $90.4 \%$ of the total ovary area (Table 2, Fig. 1).

Ascertained in the ovaries of female no. 35 was a small quantity of primary and growing follicles (Table 3), probably connected with the age of the animal. Further a considerable quantity of mature Graafian fol-

Table 2

Areas of cross-sections of the beaver ovaries, measured on microphotographs.

\begin{tabular}{lrrrr}
\hline \multicolumn{1}{c}{ Measurement } & \multicolumn{3}{c}{ No. of animal } \\
& 35 & \multicolumn{1}{c}{106} & \multicolumn{1}{c}{99} \\
\hline Area of cross-section of the whole ovary $\left(\mu^{2}\right)$ & 223,365 & 36,075 & 42,372 \\
Area of the vascular layer (in $\left.\mu^{2}\right)$ & 19,730 & 8,399 & 9,957 \\
Area of the follicular layer (in $\mu^{2}$ ) & 203,635 & 27,676 & 32,415 \\
Individual layers as per cent of the cross-section of the & 9.6 & 23.3 & 23.5 \\
whole ovary: (1) vascular layer & 90.4 & 76.7 & 76.5 \\
\hline (2) follicular layer & & & \\
\hline
\end{tabular}

Table 3

A numerical characteristic of the left and right ovaries of females investigated. $\mathrm{A}-$ absolute number, $\mathrm{B}-$ mean in $\mu$.

\begin{tabular}{|c|c|c|c|c|c|c|c|c|c|c|c|}
\hline \multirow{2}{*}{\multicolumn{2}{|c|}{$\begin{array}{l}\text { No. of } \\
\text { animal }\end{array}$}} & \multicolumn{2}{|c|}{$\begin{array}{l}\text { Primary } \\
\text { follicles }\end{array}$} & \multicolumn{2}{|c|}{$\begin{array}{l}\text { Growing } \\
\text { follicles }\end{array}$} & \multicolumn{2}{|c|}{$\begin{array}{l}\text { Mature } \\
\text { follicles }\end{array}$} & \multicolumn{2}{|c|}{$\begin{array}{l}\text { Atretic } \\
\text { follicles }\end{array}$} & \multirow{2}{*}{\multicolumn{2}{|c|}{$\begin{array}{l}\text { Corpora } \\
\text { A }\end{array}$}} \\
\hline & & A & B & A & B & A & B & A & B & & \\
\hline 35 & $\begin{array}{l}\mathrm{L} \\
\mathrm{R}\end{array}$ & $\begin{array}{l}3,188 \\
5,724\end{array}$ & $20-28$ & $\begin{array}{l}71 \\
37\end{array}$ & $56-275$ & $\begin{array}{l}22 \\
18\end{array}$ & $795-1270$ & $\begin{array}{l}7 \\
2\end{array}$ & $950-1520$ & $\begin{array}{l}28(9)^{*} \\
23(9)^{*}\end{array}$ & $2836-3790$ \\
\hline 106 & $\begin{array}{l}\mathrm{L} \\
\mathrm{R}\end{array}$ & $\begin{array}{l}30,492 \\
27,307\end{array}$ & $14-19$ & $\begin{array}{l}502 \\
436\end{array}$ & $29-167$ & $\begin{array}{l}6 \\
5\end{array}$ & $368-565$ & $\begin{array}{l}16 \\
11\end{array}$ & $237-490$ & $\begin{array}{l}4 \\
7\end{array}$ & $1235-1864$ \\
\hline 69 & $\begin{array}{l}\mathbf{L} \\
\mathrm{R}\end{array}$ & $\begin{array}{l}18,188 \\
19,071\end{array}$ & $14-20$ & $\begin{array}{l}291 \\
365\end{array}$ & $38-193$ & $\begin{array}{l}9 \\
7\end{array}$ & $287-495$ & $\begin{array}{l}21 \\
20\end{array}$ & $320-476$ & - & 一 \\
\hline
\end{tabular}

* in brackets - the number of corpus hemorrhagicum.

licles and forming corpora lutea in various stages of development indicated a marked increase in gonade activity. At the time of the death of this female there were in each ovary about 20 Graafian follicles in the final stages of maturing. Moreover, part of the follicles, after ovulation, were in the stage of corpus hemorrhagium with large blood clots, and part in the advanced stage of resorbing the follicular fluid and blood clots (Fig. 1). Also, there existed corpora lutea with lutein cells in a state of being formed. In total, in the left ovary there existed 28 and in the 
right 23 corpora lutea forming and in various stages of development. There were comparatively few atretic follicles.

Thus it seems that the hormones administrated in the period of reproductive inactivity caused an inverate superovulation. The first ovulations in this prolonged cycle caused changes in the females reproductive tract, characteristic for the luteal stage. The oviduct walls had a thick mucous membrane covered with a low unistratal epithelium (Fig. 4), the cells of which were in the excretory phase. Noticeable was the vacuolation of epithelial cells of the basal part of the mucous membrane. On the cross-sections of the uterus it was possible to observe that the surface epithelium of the mucous membrane and the glandular epithelium had cells of irregular shape. There were found fragments of disintegrating cells and drops of secreta in the uterus lumen (Fig. 5). Numerous vacuoles were noticed in the cells. The epithelial cells were rather low. The changes in the uterus glands are accompanied by changes within the connective-tissue stroma. The cells of the connective tissue are globular in shape and congest in the functional part of the mucous membrane of the uterus. The muscular coat of the uterus also increased its width reaching $15 \mathrm{~mm}$ in the proximity of cervixes uteri.

The structure of the vagina walls indicated an early metoestrus. In the mucous membrane there was a thick multistratal squamous epithelium, the external layers of which were desquamating. The proliferation process was not yet completed, indicating a recent ovulation (Fig. 7).

In the control females, nos 69 and 106, the area of the follicular layer was considerably smaller than in female no. 35 . This layer constituted only $23 \%$ of the overall area of the ovary cross-section (Fig. 3).

The ovaries of female no. 69 were in the final follicular phase. In the ovary, there were 7 to 9 follicles and about 20 follicles in the atretic phase (Fig. 2). In the oviducts of this female there was a comparatively high unistratal columnar epithelium without symptoms of vacuolation and secretion. In the uterus, a lengthening and expension of the glandular tabules was ascertained while the mucose membrane was lined by a high cylindrical glandular epithelium, manifesting no excretion symptoms. The vagina mucose membrane was softened, created numerous longitudinal folds. The multistrate squamous epithelium lining the mucose membrane did not indicate proliferation.

The ovaries of female 103 had a smooth surface with noticable russet spots where the follicles ovulated and demonstrated an early luteal phase. The ovulation must have occurred more or less simultaneously in all the mature Graafian follicles, the corpora lutea were in the same development phase (Fig. 3). In the ovaries of this female there were also many atretic follicles (Table 3 ) and atretic corpora lutea. The oviducts had, 
similarly to female no. 25 , the mucose membrane with the epithelium in a secretion phase. Changes in the uterus testifying the approach of the endometrium glands to the secretion stage (Fig. 6) were similar to those ascertained in female no. 35. Similarly, in the vagina mucose membrane there occurred a multistratal squamous epithelium with desquamating external layers, typical of the early monoestrus.

\section{DISCUSSION}

Comparison of the reproductive tracts of the experimental and control females makes it possible to ascertain that the hormones administered to female No. 35 caused, outside the normal mating season, a protracted superovulation, lasting more than a dozen days. This superovulation is accompanied by an excessive enlargement of the ovaries, principally of their follicular layer, and of the reproductive tract. In addition to the persisting oestral phase of the ovaries there occurred in them and in the reproductive tract changes characteristic of the luteal phase. Consequent on inadequate quantities and balancing of gonadotrophic hormones in the organism, an overlapping took place of two phases of the sexual cycle. However, the hormones administered did not cause the appearance of external symptoms of oestrus, and the female was not fertilised. It seems that further experiments on provoking oestrus and ovulation with hormones must be carried out on the basis of considerably lower hormone doses.

\section{REFERENCES}

1. Doboszyńska T., 1974: Histomorfologia układu rozrodczego samicy bobra europejskiego (Castor fiber L.). Diss., Akademia Rolniczo-Techniczna w Olsztynie: $1-91$.

2. Domański E., 1970: Regulacje neuro-hormonalne procesu owulacji i rui u ssaków. Zesz. probl. Post. Nauk roln., 108: 25-39.

3. Donovan B. T., 1967: Control of follicular growth and ovulation. Laming and Amoroso, Reproduction in the Female Mammal: 3-29. London.

4. Gemzell C., 1967: Control of ovulation with human gonadotrophins. Laming and Amoroso, Reproduction in the female mammal: 212-222. London.

5. Gordon J., 1971: Hormones in aut-of season breeding in sheep. Kongres Europejskiej Federacji Zootechnicznej, Helsinki 23-26.VI.1969. [after: Przegląd nauk. Lit. zootech., 1: 91-96].

6. Iva nova T. M., 1961: Godovaja cikliěnost spermatogeneza rečnogo bobra. Trudy voronozh. gos. Zapov., 12: 117-138.

7. Jöhle W. \& Plato Alto, 1970: Allgemeine Methodik und rerwendete Präparate in der Zyklusstenerung bei Haustieren. Der Tierzüchter, 22, 3: 65-67.

8. K a r d y mowicz M., 1970: Badania nad synchronizacją rui i owulacji u owiec w Instytucie Zootechniki w Polsce. Zesz. probl. Post. Nauk roln., 108: 82-89. 
9. Karg H., 1970: Physiologische Grundlagen der Stenerung des Sexualzyklus. Der Tierzüchter, 20, 3: 63-65.

10. Kremer M., 1970: Badania nad wywoływaniem i synchronizacją rui i owulacji u owiec w okresie anoestrus. Zesz. probl. Post. Nauk roln., 108: 127-128.

11. Lavrov L. S., 1960: K voprosu o biologičeskih i morfologičeskih različjah mieždu evropejskimi i kanadskimi bobrami. Trudy voronozh. gos. Zapov. 11:: $103-120$.

12. Robins on T. J., 1967: Control of the ovarian cycle in the sheep. Laming and Amoroso, Reproduction in the female mammal: 373-418. London.

13. Robins on T. J., 1970: Brunstsynchronisierung beim Schaf. Der Tierzüchter, 22, 3: 75-79.

Accepted, September 25, 1974.

Agricultural and Technical Academy,

Institute of Fundamental Veterinary Sciences

10-957 Olsztyn - Kortowo, Poland.

and

Polish Academy of Sciences,

Institute of Genetics and Animal Breeding,

Popielno, 12-222 Wejsuny, Poland.

\section{Teresa DOBOSZYŃSKA i Wirgiliusz ŻUROWSKI}

\section{ZMIANY W UKEADZIE ROZRODCZYM SAMICY BOBRA OBSERWOWANE PO PODANIU WYSOKICH DAWEK HORMONOW GONADROPOWYCH}

\section{Streszczenie}

W doświadezeniu nad hormonalnym sterowaniem rozrodem u bobrów europejskich, samicy $\mathrm{nr} 35$ podano u schyłku okresu nieaktywności rozrodczej, w ciągu 13 dni $5 \mathrm{mg}$ estrogenu i $70 \mathrm{mg}$ progesteronu, a następnie $1000 \mathrm{jm}$ PMSG i $1000 \mathrm{jm}$ HCG. Samica została zabita 14 dnia po ostatniej injekcji gonadotropiny. Jej układ rozrodezy poddano badaniom histologicznym. Na ich podstawie stwierdzono, że podane hormony spowodowały przewlekłą, trwającą kilkanaście dni superowulację. W drogach rodnych samicy dało się wyodrębnić zmiany charakterystyczne zarówno dla fazy follikularnej jak i lutealnej cyklu. Na skutek niewłaściwych ilości i wyważenia hormonów gonadotropowych w organizmie, doszło do nałożenia się na siebie dwu faz cyklu płciowego. Obserwowano także nadmierny rozrost organów rozrodczych, spowodowany prawdopodobnie nadmiarem hormonów gonadotropowych. 


\section{EXPLANATION TO PLATES}

\section{Plate III}

Fig. 1. Cross-section of ovary.

Superovulation - different stages of formation of the corpora lutea: 1 - corpus hemorrhagicum with blood clot, 2 - corpus luteum at any early period of retrogression of the contents of the follicular cavity, 3 - fragments of corpora lutea with a layer of lutein cells in the process of formation. No. 35 female. Mallory's stain. Fig. 2. Ovary prior to ovulation.

1 - mature Graafian follicles, 2 - a growing follicle, 3 - numerous atretic follicles. No. 69 female. Mallory's stain.

Fig. 3. Fragment of ovary holding corpora lutea in the process of formation. 1 - corpora lutea. No. 106 female. Mallory's stain.

Fig. 4. Alterations in the oviduct evoked by the administred gonadotrophic hormones. Softened mucous membrane, proliferation of the epithelium and disintegration of its cells; the secretory phase. No. 35 female. Haematoxylin-eosin stain.

Plate IV

Fig. 5. Secretory phase of the mucous membrane epithelium and of the uterine glands.

1 - secretory epithelium of the mucous membrane, 2 - uterine gland at the secretory phase, 3 - active layer of the mucous membrane with a dense cellular texture. No. 35 female. Haematoxylin-eosin stain.

Fig. 6. Appearance of uterine glands in their secretory phase - no. 106 female which lost its life in the breeding season. Haemotoxylin-eosin stain.

Fig. 7. Mucous membrane of the vagina. Squamous, multistratal epithelium showing no symptoms of complete keratosis; cells of the surface layer occurring in scarce numbers, are subject to desquamation. No. 35 female. Haemotoxylin-eosin staining. 
ACTA THERIOLOGICA, Vol. XX, 8.

Plate III.

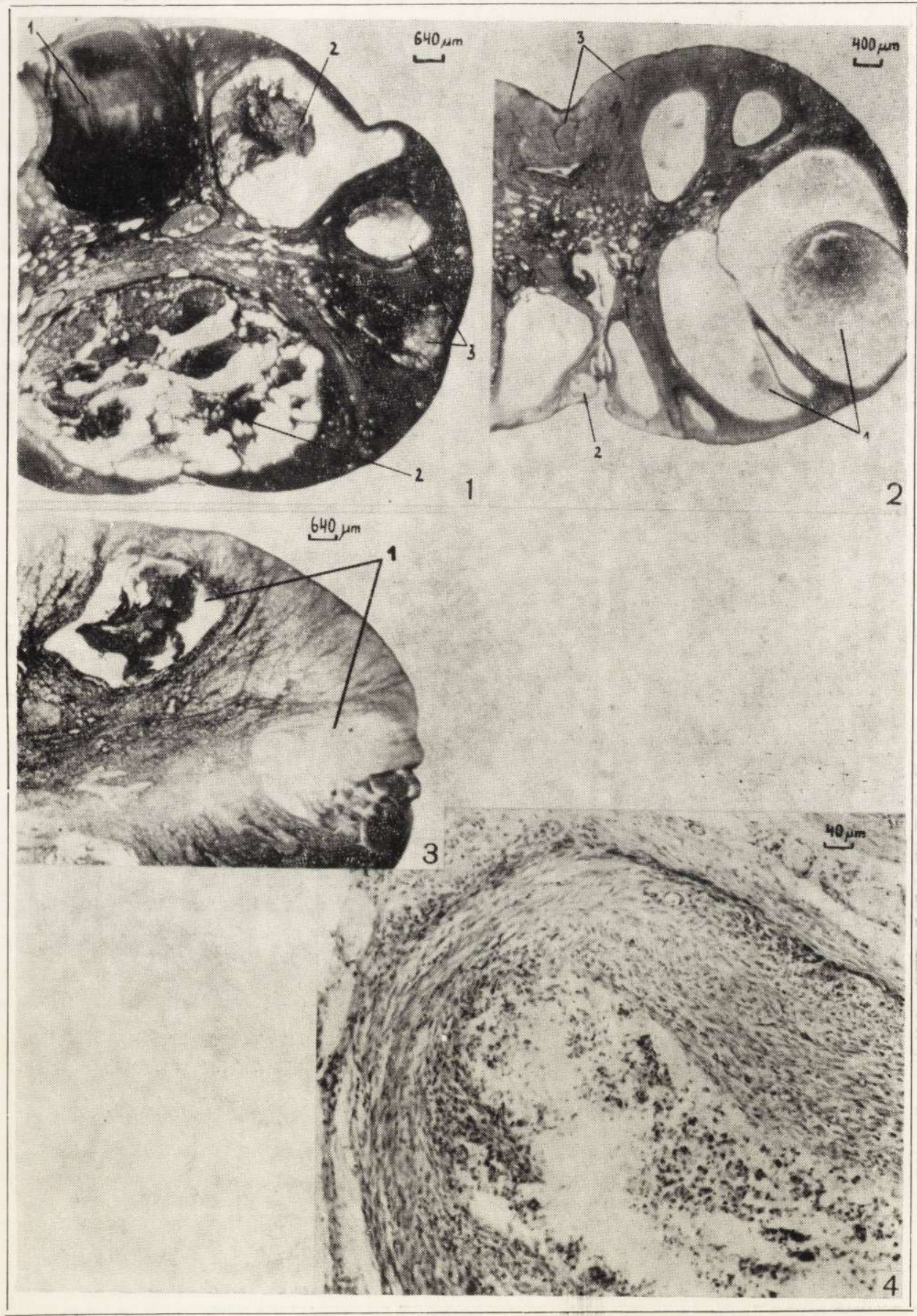

T. Doboszyńska \& W. Żurowski

C. Nagięć phot. 


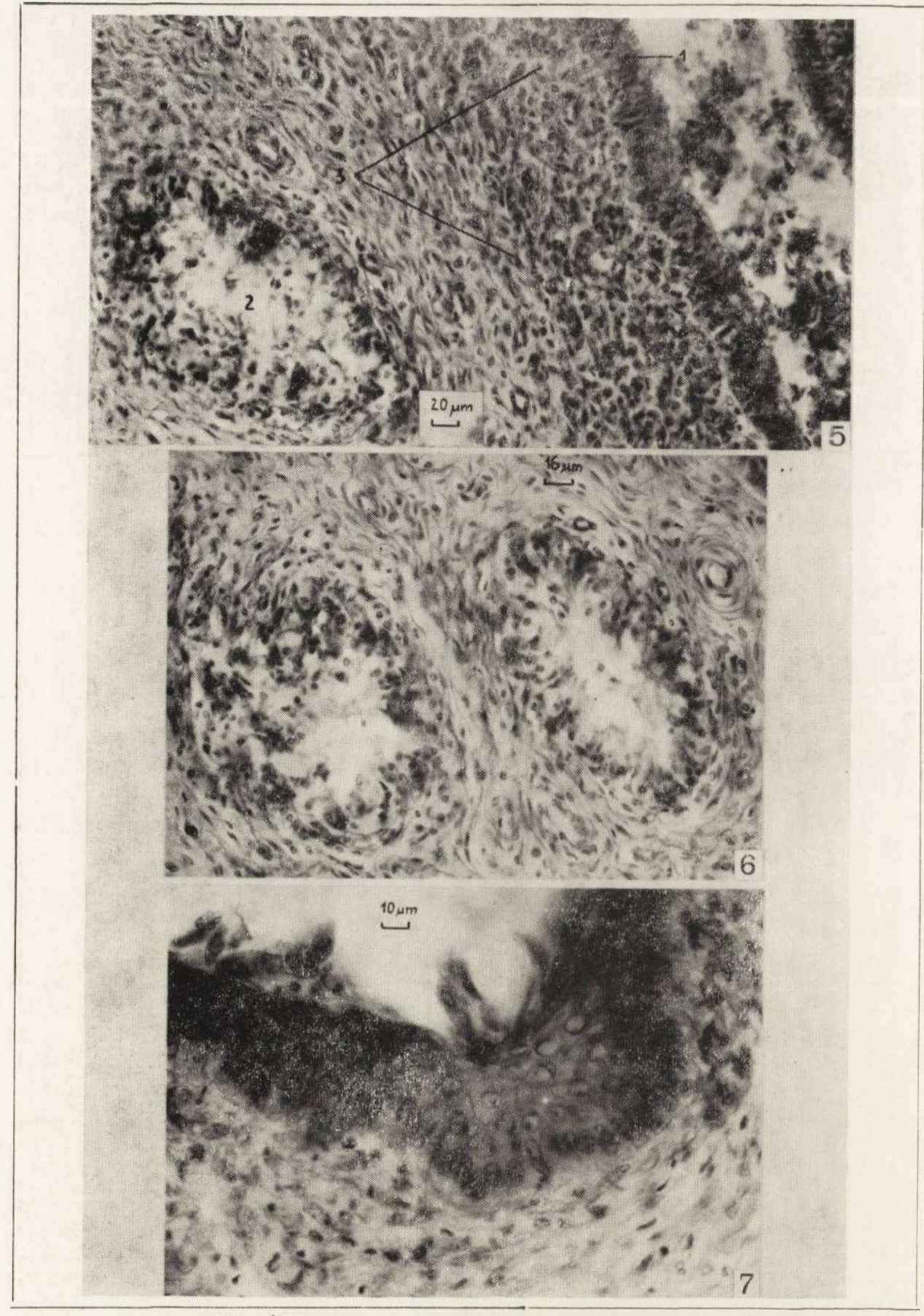

T. Doboszyńska \& W. Żurowski

C. Nagięć phot. 